Marquette University

e-Publications@Marquette

$5-1-2008$

Sexual Mores, Ethical Theories, and the Overpopulation Myth

Howard P. Kainz

Marquette University, howard.kainz@marquette.edu

Accepted version. Heythrop Journal, Vol. 49, No. 3 (May 2008):361-369. DOI. (c) 2008 Wiley. Used with permission.

The definitive version is available at www3.interscience.wiley.com. 


\title{
Sexual Mores, Ethical Theories, and the Overpopulation Myth
}

\author{
Howard Kainz \\ Department of Philosophy, Marquette University \\ Milwaukee, WI
}

\begin{abstract}
Some of the causes of the 'sexual revolution' during the past few decades are widely known: The development of relatively safe and reliable contraceptives, especially the birth-control pill; the 'morning after' pill; antibiotics to relieve or cure sexually transmitted diseases such as gonorrhea, herpes, and syphilis; the increased social acceptance of pre-marital sex, homosexuality, and other behaviors that formerly were considered deviant; and the legalization of abortion as the ultimate 'contraceptive'. But little attention has been paid to two rather cerebral factors relevant to these developments - namely, ethical theories, and theories of overpopulation. In this paper I will argue that these two less well-known and more subtle factors have been at least as powerful as the more obvious factors mentioned above, in bringing about sea-changes in sexual mores. More specifically, I will argue that some implicit approaches to ethical theory are more conducive than others to bringing about the present status quo in sexual mores, and that the widespread belief in world overpopulation has not only changed the moral climate regarding sexuality, but has helped to redefine what is moral and what is immoral.
\end{abstract}

\section{Prevailing Moral Theories}

It is a good question whether moral theories come before or after actual human behavior. Although college classes in ethical theory commonly feature analyses of Kant's Categorical Imperative or Rawls'

Heythrop Journal, Vol. 49, No. 3 (May 2008): pg. 361-369. DOI. This article is @ Wiley and permission has been granted for this version to appear in e-Publications@Marquette. Wiley does not grant permission for this article to be further copied/distributed or hosted elsewhere without the express permission from Wiley. 
theory of justice, it is unlikely that those who have learnt these theories, when facing a moral decision, would sit down and try to determine whether their personal maxim can pass the 'universalization' test, or abstract from all their advantages and interests and try to put themselves in a Rawlsian 'original position'. Possibly a few extremely cerebral professional moral theorists might try to work out personal applications of their theories, when faced with a moral decision. But it is much more likely that, for professionals and 'everyman', moral theories sum up the sorts of principles that people already habitually follow, in making choices concerning right and wrong.

If we wished to categorize these principles under the rubric of prevailing moral theories, a likely candidate for the implicit ethical commitment of denizens of modern industrial societies would be utilitarianism. Of course, very few people, even professed utilitarians, will reach for pencil and paper, to calculate positive and negative Benthamite 'units of happiness'; they will content themselves with 'ballpark' calculations. But many, going beyond ego-centered questions of personal advantage, will engage in serious 'considerations of utility' concerning the effect of their actions on the happiness of others, and in their actions will try to avoid inflicting suffering on others. In this sense, a utilitarian approach does seem to be the 'method' by which many people in cultures such as ours make their moral decisions - and it is a procedure that jibes very well with democracy and the 'majority' principle. Just as we expect democratic leaders to work for the greater satisfaction of their constituents, so also we tend to judge our own moral caliber, by examining the beneficial or deleterious effects our actions have on those about us. Thus, even though most people have never studied utilitarian theory, a minimal, common-denominator utilitarianism may be their 'rule of thumb', or main strategy, for moral decision-making.

As applied to sexuality, a utilitarian approach may emphasize maximizing enjoyment for all parties while avoiding harm in sexual encounters. The logical conclusion for those who think in this utilitarian fashion, outside the parameters of traditional mores and religious prohibitions, is the approval of anything between 'consenting adults' in other words, prohibition of rape, incest, pedophilia, and any kind of sexual congress involving force or lack of consciousness, but acceptance of anything else. Thus contraception, pre-marital

Heythrop Journal, Vol. 49, No. 3 (May 2008): pg. 361-369. DOI. This article is @ Wiley and permission has been granted for this version to appear in e-Publications@Marquette. Wiley does not grant permission for this article to be further copied/distributed or hosted elsewhere without the express permission from Wiley. 
cohabitation, and gay marriage are widely considered morally acceptable from a utilitarian vantage point, as long as the resulting benefits seem to outweigh any negative consequences. For those who confine their purview of consequences to existing persons, abortion is also acceptable, if it is considered conducive to the mental or physical health, or psychological fulfillment, or social advancement, of the mother; as well as conducive to a decrease in crime, decrease in welfare entitlements, etc. At present, most utilitarians would want to avoid harm to children and adolescents through sexual relationships with adults, although some argue that consent is possible in such cases. But consensual sex is a 'slippery slope': the prohibition of pedophilia and ephebophilia is likely to be eventually relaxed, under the rubric of extending experiences of pleasure even to consenting children. This has already taken place in Holland, where twelve-yearolds are considered capable of engaging in consensual sexual activities.

Another leading contender among prevailing but implicit moral theories is the Golden Rule, 'do unto others as you would have them do unto you', or, expressed negatively, 'do not do to others what you would not want them to do to you'. The positive version, attributed to Jesus (Matthew 7:12, Luke 6:31), not only has Biblical sanction, but is also akin to modern 'universalization' moral theories (e.g., 'consider whether you would want your personal moral maxim to be a universal rule for everybody'), considered by proponents like Kant to be more sophisticated and philosophically sound than the traditional Christian formulation of the Golden Rule. But many 'persons on the street', unacquainted with ethical theories, operate according to the Golden Rule. Although they may not think about this as their principle for moral action, it is applied tactically in their decision-making, and transmitted by parents to their children in informal discussions of values.

In sexuality, the Golden Rule emphasizes logical consistency in your actions, and in what you expect from others. Contraceptive acts might be considered to constitute an issue outside the parameters of the Golden Rule, since contraception is portrayed as a private matter, and is not, strictly speaking, 'doing' anything to anybody. The Golden Rule can lead many to the condemnation of abortion, if they consider the fetus a person, since most people could not consistently want to have been aborted, themselves. Homosexuality is an ambiguous area.

Heythrop Journal, Vol. 49, No. 3 (May 2008): pg. 361-369. DOI. This article is @ Wiley and permission has been granted for this version to appear in e-Publications@Marquette. Wiley does not grant permission for this article to be further copied/distributed or hosted elsewhere without the express permission from Wiley. 
Homosexual activities may be considered consistent with the Golden Rule, insofar as the homosexual might claim that he or she is doing to another what they would want the other to do to them. On the other hand, it might be considered a pattern of life responsible for perverting the youth, undermining marriage, spreading disease, etc. - not the sort of 'right' that you would want to be given to yourself and also, consistently, to others. And if one defines sex in terms of the malefemale relationship, homo-sexuality would turn out to be a misnomer.

Less ambiguous in regard to sexual matters, and also possessing Biblical credentials, is the concept of a natural law. St. Paul adumbrates this idea in Romans 2:14-15, where he discusses God's judgment of the Gentiles, who were not subject to the Jewish law:

When the Gentiles, who have not the law, do by nature the things contained in the law, they, having not the law, are a law unto themselves. They show the work of the law written in their hearts, their conscience bearing witness, and their thoughts accusing or else excusing one another on the day when God judges what is hidden in men.

Paul hailed from Tarsus, which was a hotbed of Stoic philosophy, a major ancient source of natural-law thinking. It is quite possible that Paul was familiar with the Stoic theories, although there is nothing but circumstantial evidence for such intellectual influence. The specific applications of the 'law of nature' that Paul cites in Romans 2:21-22 are primarily the mandates included in the Decalogue - against stealing, adultery, etc. Paul's implication is that such laws, rooted in human nature, were indeed given more explicit expression in Moses' time, but were by no means the exclusive heritage of the Jews.

In philosophical circles, the idea of a natural law in morals was further developed by later Stoic philosophers, incorporated into Roman legal thinking by classical jurists such as Ulpian and Gaius, and subjected to further refinement by medieval scholastics, especially St. Thomas Aquinas, who fortified natural-law theory with Aristotelian metaphysics and psychology. In the late medieval era, Renaissance and Enlightenment, both Catholic and Protestant ethicists refined and perpetuated natural law theory, before it was overshadowed by utilitarianism, Kantian universalism, and other theories in the nineteenth and twentieth centuries. ${ }^{1}$

Heythrop Journal, Vol. 49, No. 3 (May 2008): pg. 361-369. DOI. This article is (C Wiley and permission has been granted for this version to appear in e-Publications@Marquette. Wiley does not grant permission for this article to be further copied/distributed or hosted elsewhere without the express permission from Wiley. 
But two twentieth-century developments have given an impetus to the revival of natural-law thinking: The first was the Nuremberg trials at the end of World War II, which raised the question: is there some superior law that can be used as the criterion justifying the court's judgment of Nazi officers, who were arguably following valid laws of the land? The second development was Pope Paul VI's 1968 encyclical letter on birth control, Humanae vitae, which invoked natural law as well as religious incentives against the use of artificial contraceptive devices to avoid pregnancy. The Pope's position was criticized by many ethicists and has been the catalyst for a crisis of authority in the Church. However, many natural-law theorists came to the defense of the Pope, and their writings have led to a further exploration both of the theoretical foundations of natural law, and of the applications which it may have in law and in morals.

Opposition to natural-law theory in the twentieth century has been largely fueled by dogmatic adherence among analytic ethicists to David Hume's famous interdiction about 'deriving an "ought" from an "is"; other analytic commitments include a sacrosanct observance of the 'fact-value' distinction, and resolute avoidance of the 'naturalistic fallacy'. Natural-law theory, since it purports to find certain ethical norms rooted in human nature itself, seems to break these established rules. I and other writers have argued that natural law, as traditionally understood, is not indeed guilty of an infraction of any of these metaethical rules. ${ }^{2}$ However, largely as a result of such criticisms, in the last few decades the natural-law tradition has split into two 'camps' - the 'new natural law' theorists, which claim to support a version of natural law which obviates Humean objections, and the traditional natural-law theorists. ${ }^{3}$ These two camps are in disagreement about metaphysical or anthropological presuppositions (whether there can be a grounding in human nature itself for moral norms), but maintain a large bedrock of agreement on many practical issues. In sexuality, a pivotal principle concerns the necessary connection of sexuality with reproduction, and/or the avoidance of 'contra-life' sexual practices. Contraception is opposed, as bringing about an absolute artificial separation of sexuality from the production of new life - a separation which can lead by a 'slippery slope' to the legitimation of 'recreational sex' of all types, including fornication and homosexual activities. Various types of Natural Family Planning (NFP) are, however, considered by most natural-law theorists to be morally

Heythrop Journal, Vol. 49, No. 3 (May 2008): pg. 361-369. DOI. This article is @ Wiley and permission has been granted for this version to appear in e-Publications@Marquette. Wiley does not grant permission for this article to be further copied/distributed or hosted elsewhere without the express permission from Wiley. 
acceptable: e.g., the Billings Ovulation Method, the Sympto-Thermal Method, and the Standard Days Methods. With these methods, the knowledge of ovulation states can be used either to promote or to delay fertility, and does not necessarily involve any direct contra-life intention.

Objections to the Pope's invocation of natural law in Humanae vitae often cite the alleged unreasonableness of requiring that every single act of sexual intercourse be oriented toward reproduction. This interpretation is a mistake. Like many directives of natural law, the obligations with regard to sexual intercourse are not spelled out as multiple positive duties; only certain negative boundaries are pointed out. Some examples from other precepts of the natural law can help to clarify the importance of these 'negatives': For instance, the duty of telling the truth does not imply that we have to give everyone the positive information that they may request from us, but only that we do not tell them falsehoods; the duty of self-preservation does not entail that we must take all available vitamins, 'work-out' regularly, receive optional surgical procedures, etc., but only that we do nothing that would be seriously contrary to preserving oneself - suicide being the most extreme example; the duty of advancing in knowledge of God does not require us to engage in theological investigations, but only to avoid an ideological mind-set which shuts out any possibility of such knowledge; and the duty of advancing rational social structures does not mean we must perform this or that specific and highly esteemed action for community betterment, but only that we avoid anything that will contribute to serious social disintegration. Like the daimon of Socrates, which he describes in Plato's Apology as counseling only what Socrates should not do, but not what he should do, natural-law directives, like the last seven commandments of the decalogue, focus on some ultimate 'thou shalt nots', setting certain parameters beyond which morality would ipso facto be abandoned. In the case of a natural-law approach to sexuality, the limiting parameters have to do with types of sexual intercourse intended to make reproduction impossible. In Natural Family Planning, merely refraining from intercourse during presumed fertile periods is not a transgression of those parameters. In using abortifacient contraceptives such as IUDs, Norplant and Depo-Provera, not only is the contra-life intention clear; but the two issues of abortion and contraception begin to converge - as also with the use of

Heythrop Journal, Vol. 49, No. 3 (May 2008): pg. 361-369. DOI. This article is @ Wiley and permission has been granted for this version to appear in e-Publications@Marquette. Wiley does not grant permission for this article to be further copied/distributed or hosted elsewhere without the express permission from Wiley. 
contraceptive pills, which sometimes work after fertilization to prevent implantation of the fertilized egg. Even those who view contraception as morally permissible, but are opposed to abortion, sometimes have objections to the use aborifacient contraceptives.

Some Christian ethicists make a sharp distinction between sexual intercourse as reproductive, and, on the other hand, as contributing to love and communion among spouses. They say that since these aims are equally important in marriage, a couple might cultivate just the latter aim, especially if the former aim is perceived as an obstacle to marital communion. But this is an artificial and stark separation of the aims of individuals from the aims of nature - like separating eating as enjoyment of the fruits of nature from its contribution to health - after the pattern of the ancient Roman vomitoria, which allowed participants in banquets to eat for hours and hours without stop, or (to cite a more contemporary phenomenon) the eating disorder, bulimia. (As in the examples cited above, the 'negatives' are important here; no one is saying that every act of eating has to be positively directed towards conservation of health, but only that an act which clearly scorned the purpose of eating in the pursuit of pleasure is unnatural and immoral.) Everyone knows that love or affection are very often not connected with sexual intercourse, and in fact indifference or hate are often the unfortunate concomitants of the act; but for nature itself, even construed in the context of Darwinian 'natural selection', the 'intent' of reproduction is always a concomitant of the sex act. A natural-law approach leads us to join our purposes with the implied purposes of nature as far as possible.

\section{The Overpopulation Myth}

The widespread diffident attitude toward natural law (due in large part to a misunderstanding of the meaning of natural law) is not the only, or even the most important, catalyst for altering the moral landscape of sexuality. An even more serious challenge to traditional standards of sexual morality is the widespread belief, often a tenet of scientific 'faith', that the world is overpopulated, and that we must do everything possible, individually and socially, to curb the number of offspring. This belief is often described as 'neo-Malthusianism', referring to the now-discredited eighteenth-century theory propounded by Thomas Malthus. Malthus theorized that, while the world's foodsupply increased in arithmetical proportion, the world's population

Heythrop Journal, Vol. 49, No. 3 (May 2008): pg. 361-369. DOI. This article is (C Wiley and permission has been granted for this version to appear in e-Publications@Marquette. Wiley does not grant permission for this article to be further copied/distributed or hosted elsewhere without the express permission from Wiley. 
increased in geometrical proportion. This exponential growth of population, according to Malthus, would inevitably bring about the depletion of the world's resources and concomitant famine, disease, poverty, etc.

Early in the twentieth century, eugenicists formed the first flank in the battle against overpopulation. Margaret Sanger, citing the inspiration of Malthus and John Stuart Mill, ${ }^{4}$ opted for the elimination of 'defectives' in world populations by the use of contraceptives, and supported the efforts of the 'Malthusian League' to incorporate population reduction into the agenda of the League of Nations. ${ }^{5}$ In recent decades, and in an even more hysterical fashion, the NeoMalthusian, Paul Ehrlich, has been warning about catastrophic results of overpopulation. Ehrlich in his best-selling book of the sixties, The Population Bomb, ${ }^{6}$ predicted that by the end of the twentieth century hundreds of millions would die of starvation, India would collapse, England would disappear, etc. Ehrlich's message, like Malthus' message, was that the world's population is rapidly outstripping the food supply of the planet, as if the food supply were something progressing in regular arithmetical intervals. But in fact the world's food supply has steadily increased in something like 'geometrical' proportion; and with the help of agricultural technology and human ingenuity, food supplies can continue to increase in tandem with population. ${ }^{7}$

Nevertheless, motivated only by ideology, and in spite of the fact that many European countries have arrived at such low birth levels that their continued existence is threatened, activists for contraception and abortion still invoke a 'population explosion'. And the perception that there is just too little space for the people of the world persists - in spite of the fact that for the present 6.2 billion people in the world, outside Antarctica, there is about 246,000 square feet per person, and in spite of the fact that if the population of the entire world were relocated just in Texas in the United States, each person would have approximately 1300 square feet per person! The 'space' in such statistical projections would include, of course, mountains and deserts, but also oases and valleys and fertile plains; and 'horizontal' space can be supplemented with 'vertical' space multi-storey buildings, etc.

It is obvious that what is called the 'overpopulation problem' is not a space problem, but more precisely a problem of distribution of

Heythrop Journal, Vol. 49, No. 3 (May 2008): pg. 361-369. DOI. This article is @ Wiley and permission has been granted for this version to appear in e-Publications@Marquette. Wiley does not grant permission for this article to be further copied/distributed or hosted elsewhere without the express permission from Wiley. 
wealth and resources - a political/social/ethical issue. Even if, through massive worldwide sex education, the distribution of condoms, sterilization, etc., the world's population could be reduced by one-sixth to around five billion, there is no guarantee that the percentage (or even the numbers) of poor people would be reduced; the ratio of impoverished to the well-fed could even grow to greater heights. Worst-case scenarios may prevail. For example, even after such a hypothetical reduction in population, parents with fewer children may have less help in farming work, fewer contributors to the family finances, and less assistance from family members in their old age; employers, aware that families are smaller, may cut wages proportionally; government officials, administering a decreasing population, may curtail distribution of resources and/or raise taxes to increase revenues; and so forth. Simple formulas for reducing the number of children can have no predictable effect on such problems.

The effect of neo-Malthusianism on Christian ethics is little noticed, but enormous. In spite of the failure of the predictions of overpopulation gurus to come true, many now consider the Biblical mandate, 'increase and multiply' (Genesis 1:28) to be outmoded possibly significant for our distant ancestors, but no longer applicable even for those who adhere to Judaeo-Christian traditions. Put differently, the common modern wisdom maintains that we have fulfilled this command. The argument goes: God should certainly be satisfied with our numbers now; and - although God hasn't revealed His will about this in any explicit way - presumably He wills us to follow what is generally held to be the 'best' science today. Needless to say, the moral fallout of the overpopulation myth has been considerable. By many committed to overpopulation dogma, it is now considered to be a virtue to do anything possible to avoid reproduction.

The combination of the rejection of the natural law regarding contraception and a pseudo-scientific and quasi-religious commitment to reducing the world's population, combined with the other cultural and technological developments mentioned at the outset of this paper, leads not illogically to wide-ranging changes in sexual morality. If contraception is legitimate for married couples, why not also for any 'consenting adults' - granted that the latter are motivated by love as much as, or even more than, married couples? And why draw a line for 'consent' at some artificial measure of 'legal adulthood', like eighteen

Heythrop Journal, Vol. 49, No. 3 (May 2008): pg. 361-369. DOI. This article is (C Wiley and permission has been granted for this version to appear in e-Publications@Marquette. Wiley does not grant permission for this article to be further copied/distributed or hosted elsewhere without the express permission from Wiley. 
years of age? Likewise, homosexuality and masturbation, which by definition eschew reproduction, can easily be construed as advancing social objectives such as 'zero population growth'. Even pornographers might consider themselves moral standard-bearers for promoting the pursuit of innocuous personal pleasure rather than selfish and inconsiderate family breeding. Abortion, for a liberal Christian, extremely distraught about uncontrollable population growth and dedicated to the affirmation of women's rights, might be considered the 'lesser of two evils' - the 'other evil' being inconsiderate additions to the world's population.

The synergetic effect of the combination of the contraceptive mentality with overpopulation hysteria may be lessened if we begin to grapple with the real overpopulation issue - recognizing the realities underlying this issue, recognizing the injustices and inequities prevailing in domains such as politics, economics, and business. The fact that, for example, the United States, with $5 \%$ of the world's population, is consuming $30 \%$ of the world's resources, cannot be ignored. Our growing awareness of this imbalance should inspire both individual and communal efforts to right the wrongs, and reduce the gap between the 'haves' and the 'have-nots'. But - 'overpopulation' being understood as the excessive numbers of impoverished people simplistic solutions like global promotion of contraception and abortion will do nothing to alleviate global injustices; and married couples will do nothing to sustain the planet, and make no advances in personal or civic virtue, by intentionally avoiding offspring.

\section{Notes}

${ }^{1}$ For a detailed analysis of the evolution of natural law, see the historical sections (chapters 1-4) of H. Kainz, Natural Law: an Introduction and Re-examination (Chicago: Open Court, 2004).

2 Natural Law, Chapter 6.

3 Natural Law, Chapter 4.

${ }^{4}$ See Margaret Sanger, Women and the New Race (NY: Truth

Publishing Company: 1920), p. 159.

${ }^{5}$ Women, p. 162.

6 See The Population Bomb (NY: Ballantine Books, 1968).

7 Articles bringing out the fallacies of neo-Malthusianism include Colin Clark, Population Growth: The Advantages (Santa Ana: R.L. Sassone, 1972); Nick Eberstadt, 'Population and Economic Growth', Wilson Quarterly 10:5 Winter 1986; Peter T. Bauer,

Heythrop Journal, Vol. 49, No. 3 (May 2008): pg. 361-369. DOI. This article is @ Wiley and permission has been granted for this version to appear in e-Publications@Marquette. Wiley does not grant permission for this article to be further copied/distributed or hosted elsewhere without the express permission from Wiley. 
NOT THE PUBLISHED VERSION; this is the author's final, peer-reviewed manuscript. The published version may be accessed by following the link in the citation at the bottom of the page.

Development Frontier: Essays in Applied Economics (Cambridge, MA: Harvard University Press, 1991); Julian Simon, Hoodwinking the Nation (New Brunswick, N.J.: Transaction, 1999); Ronald Bailey, 'The Law of Increasing Returns', The National Interest, \#59, Spring 2000; Anthony Trewavas, 'Malthus foiled Again and Again', Nature, London, Aug. 8, 2002. 